\title{
KEDUDUKAN SAKSI INSTRUMENTER DALAM MERAHASIAKAN AKTA OTENTIK DAN PERLINDUNGAN HUKUM BAGI SAKSI INSTRUMENTER
}

\section{Puteri Chintami Oktavianti}

Universitas Tanjungpura (UNTAN) Pontianak Kalimantan Barat, Indonesia

Email: nanaminatsumi.nn@gmail.com

\section{Abstract}

Notary in carrying out its duties to make an authentic deed requires an instrumentary witness as a formal condition of authenticity of the deed made. Instrumental witnesses must comply with the statutory requirements in this case the Law on notary positions and the Law on The Notarial Position of Renewal. According to UUJN and UUJN-P explained protection against notary public and its obligation to keep the contents of the deed confidential, while the instrumenter witness is not explained clearly. In this study conducted normative legal approach that stems from the legislation and literature in accordance with this research The results obtained are instrumenter witnesses as one of the important things in the process of making authentic deed according to UUJN-P is not obliged to keep the contents of the deed confidential, Instrumenter witnesses who do not maintain the confidentiality of notary documents classified acts against the law. In UUJN-P explained legal protection against notary public, but not for instrumenter witnesses, but if one day the instrumenter witness is made a witness in a legal matter related to the deed he signed, he gets protection in accordance with the Witness and Victim Protection Act related to his position as a witness.

Keywords: instrumenter witness; concealment; protection; law

\section{Abstrak}

Notaris dalam menjalankan tugasnya membuat akta otentik membutuhkan saksi instrumenter sebagai syarat formal keotentikan akta yang dibuat. Dalam pembuatan Akta otentik disyaratkan harus terdapat saksi yaitu saski instrumenter. Saksi instrumenter harus sesuai dengan persyaratan perundang undangan dalam hal ini Undang-undang tentang jabatan Notaris yang selanjutnya disebut UUJN dan Undang-undang Tentang Jabatan Notaris Pembaruan yang selanjutnya disebut UUJN-P. Menurut UUJN dan UUJN-P dijelaskan perlindungan terhadap notaris dan kewajibannya merahasiakan isi akta, sedangkan saksi instrumenter yang juga terlibat dalam pembuatan akta otentik tidak diterangkan dengan jelas tentang kewajiban merahasiakan isi akta dan perlindungan hukumnya. Dalam penelitian ini dilakukan pendekatan hukum normatif yang bersumber dari peraturan perundang-undangan serta literatur-literatur yang sesuai dengan penelitian ini. Hasil yang diperoleh adalah saksi instrumenter selaku salah satu hal penting dalam proses pembuatan akta otentik menurut UUJN-P tidak berkewajiban untuk merahasiakan isi akta. Saksi instrumenter yang tidak menjaga kerahasiaan dokumen Notaris perbuatannya

\begin{tabular}{ll}
\hline How to cite: & $\begin{array}{l}\text { Oktavianti., Puteri Chintami (2021) Kedudukan Saksi Instrumenter dalam Merahasiakan Akta Otentik } \\
\text { dan Perlindungan Hukum Bagi Saksi Instrumenter. Syntax Literate. }\end{array}$ \\
& htt5). \\
htt//dx.doi.org/10.36418/syntax-literate.v6i5.2720 & $2548-1398$ \\
E-ISSN: & Ridwan Institute
\end{tabular}


diklasifikasikan perbuatan melawan hukum. Dalam UUJN-P dijelaskan perlindungan hukum terhadap notaris, tetapi tidak untuk saksi instrumenter, tetapi jika suatu hari saksi instrumenter dijadikan saksi dalam suatu masalah hukum yang berkaitan dengan akta yang ditandatanganinya, ia mendapatkan perlindungan yang sesuai dengan Undang-Undang Perlindungan Saksi dan Korban terkait kedudukannya sebagai saksi..

Kata Kunci: saksi Instrumenter; merahasiakan; perlindungan; hukum

\section{Pendahuluan}

Indonesia merupakan negara hukum, berdasarkan Undang-Undang dasar Negara Republik Indonesia tahun 1945 Pasal 1 ayat (3) yang mengatakan "Negara Indonesia adalah negara hukum, dalam hal ini ialah tidak ada suatu pun yang berada di atas hukum dan hukumlah yang berkuasa. Kekuasaan pemerintahan harus didasarkan atas hukum, negara dan lembaga-lembaga lain dalam menjalankan tugasnya harus dilandasi oleh hukum dan dapat dipertanggungjawabkan secara hukum. Kekuasaan menjalankan pemerintahan berdasarkan kedaulatan hukum bertujuan untuk menyelenggarakan ketertiban hukum (Hamzani, 2014). Indonesia sebagai negara berdasarkan hukum maka pemerintahan negara harus berdasar atas suatu konstitusi atau undang-undang dasar sebagai landasan penyelenggaraan pemerintahan (Budiardjo, 2003). Menurut UndangUndang No. 2 Tahun 2014 tentang Jabatan Notaris selanjutnya disebut UUJN) untuk menjamin kepastian, ketertiban, dan perlindungan hukum dibutuhkan alat bukti tertulis yang bersifat otentik mengenai keadaan, peristiwa, atau perbuatan hukum yang diselenggarakan melalui jabatan tertentu.

Akta otentik sebagai alat bukti terkuat dan mempunyai peranan penting dalam setiap hubungan hukum dalam kehidupan masyarakat. Akta otentik ini menentukan secara jelas hak, kewajiban, dan menjamin kepastian hukum, sekaligus diharapkan dapat menghindari terjadinya sengketa (Hendra, 2012). Menurut UUJN Notaris merupakan pejabat umum yang berwenang untuk membuat akta otentik. Notaris berwenang membuat akta otentik mengenai semua perbuatan, perjanjian, dan ketetapan yang diharuskan oleh peraturan perundang-undangan dan/atau yang dikehendaki oleh yang berkepentingan untuk dinyatakan dalam akta otentik. UUJN-P mengatur kewajiban notaris dalam menjalankan tugas jabatannya, khususnya dalam membuat akta otentik adalah merahasiakan segala sesuatu mengenai akta yang dibuatnya (Romadhon, 2018) Adanya kewajiban bagi Notaris untuk merahasiakan isi akta bertujuan untuk melindungi kepentingan para pihak yang terkait dengan akta tersebut. Merahasiakan isi akta juga merupakan salah satu kewajiban Notaris yang diatur dalam Pasal 16 ayat (1) huruf f UUJN-P. Dalam UUJN-P juga disebutkan bahwa salah satu kewajiban notaris adalah membacakan akta dihadapan penghadap dengan dihadiri oleh paling sedikit 2 (dua) orang saksi dan ditandatangani pada saat itu juga oleh penghadap, saksi, dan notaris. Apabila syarat ini tidak terpenuhi maka akta yang bersangkutan hanya mempunyai kekuatan pembuktian sebagai akta di bawah tangan. 
Secara umum saksi merupakan salah satu alat bukti yang diakui dalam perundang-undangan. Sebagai alat bukti yang sah, saksi adalah seseorang yang memberikan kesaksian, baik dengan lisan maupun secara tertulis atau tanda tangan, yakni menerangkan apa yang ia saksikan sendiri, baik itu berupa perbuatan atau tindakan dari orang lain atau suatu keadaan ataupun suatu kejadian (Hutapea, 2016). Saksi yang dimaksud dalam UUJN-P disebut dengan saksi instrumenter. Syarat saksi instrumenter sudah dijelaskan pada UUJN-P. Tugas dari saksi instrumenter ini adalah membubuhkan tanda tangan, memberikan kesaksian tentang kebenaran isi akta. Saksi instrumenter berfungsi membantu posisi seorang Notaris menjadi aman dalam hal akta yang dibuat oleh notaris diperkarakan oleh salah satu pihak dalam akta atau pihak ketiga (Tobing, 1992). Dalam UUJN-P tidak diatur kewajiban para saksi instrumenter untuk merahasiakan isi akta padahal saksi instrumenter banyak mengetahui mengenai keterangan isi dalam akta tersebut (Syaputri, Patittingi, \& Said, 2017). UUJN-P juga tidak memberikan perlindungan hukum terhadap saksi dalam peresmian akta, padahal saksi instrumenter dalam pembuatan akta otentik sudah memasuki jalan hukum yang mempunyai akibat hukum.

Berdasarkan penelitian yang dilakukan Daniaty pada tahun 2019 menjelaskan bahwa ruang lingkup tanggung jawab saksi instrumentair dalam pembuatan akta notaris yaitu saksi instrumentair dalam pembuatan akta otentik sebatas untuk mengesahkan akta tersebut sebagai akta otentik sebagaimana di kehendaki oleh sifat dan bentuk akta otentik, yakni ditandatangani oleh saksi notaris serta saksi instrumentair bertanggungjawab atas dipenuhinya formalitas-formalitas yang telah ditentukan oleh Undang-Undang. Saksi instrumentair dalam kaitannya dengan adanya kewajiban notaris untuk merahasiakan segala sesuatu yang berkenaan dengan akta yang dibuatnya dalam Pasal 16 ayat (1) huruf f UUJN-P, oleh undang-undang tidak diwajibkan secara tegas kepada para saksi untuk merahasiakan isi akta tersebut (I Komang Sujanayasa, 2016). Akibat hukum atas tindakan yang dilakukan oleh saksi instrumenter berkaitan dengan kerahasiaan isi akta, Notaris dapat menerapkan perbuatan melawan hukum sehingga saksi instrumenter tidak dapat dikenakan ketentuan Pasal 322 ayat (1) Kitab Undangundang Hukum Pidana, tidak adanya aturan yang mewajibkan saksi instrumenter untuk merahasiakan isi akta, menjadikan kelemahan bagi seorang Notaris sehingga perlu diadakanya kejelasan hukum kewajiban saksi instrumentair dalam merahasiakan isi akta. Selain itu apabila terjadi kasus terhadap akta yang ditandatanganinya sebagai saksi juga harus mendapat perlindungan hukum dan harus dijamin keselamatannya. Dalam UUJN-P belum dijelaskan bagaimana perlindungan hukum bagi saksi instrumentair maka perlindungan hukum terhadap saksi dalam hal ini saksi instrumentair baru dapat ditemui dalam ketentuan diluar peraturan jabatan Notaris, yakni Undang-Undang Nomor 31 Tahun 2014 tentang Perubahan atas Undang-undang Nomor 13 Tahun 2006 Tentang Perlindungan Saksi dan Korban (Kusuma, 2018). Bagaimana apabila saksi instrumentair diminta untuk memberikan kesaksian terhadap akta yang dibuat oleh Notaris yang mengalami permasalahan? hal ini memberikan informasi bahwa bukan hanya Notaris yang memiliki keharusan untuk merahasiakan isi akta notaris, tetapi 
penting bagi saksi instrumentair juga memiliki kewajiban yang sama mengingat pentingnya saksi instrumentair dalam pembuatan akta notaris, hal ini dilakukan untuk mengantisipasi permasalahan berkaitan proses pembuatan akta.

Berdasarkan uraian di atas, selanjutnya akan dibahas bagaimana kedudukan saksi instrumenter dalam merahasiakan isi akta otentik. Dan bagaimana perlindungan hukum bagi saksi instrumenter jika terlibat dalam kasus yang melibatkan akta otentik yang ditandatanganinya. Kepenulisan jurnal ini bertujuan untuk mengkaji lebih dalam tentang tanggungjawab saksi instrumentair dalam merahasiakan isi akta Notaris serta memberikan pemahaman dalam hal kedudukan hukum saksi instrumenter terkait dengan perlindungan hukum bagi saksi instrumenter, diharapkan jurnal ini dapat enambah wawasan serta perkembangan ilmu hukum pada umumnya dan kenotariatan pada khususnya serta wawasan tentang saksi instrumenter dalam pembuatan akta notaris.

\section{Metode Penelitian}

Penelitian ini menggunakan metode pendekatan hukum normatif dimana kajian bahan hukumnya bersumber dari peraturan perundang-undangan serta literatur-literatur yang sesuai dengan penelitian ini (Soekanto \& Mamudji, 2001). Dalam hal ini yaitu mengenai kewajiban saksi instrumenter merahasiakan isi akta dan perlindungan hukum untuk saksi instrumenter. Pada penelitian ini menggunakan bahan hukum primer yaitu perundang-undangan diantaranya :

1. Undang-Undang Republik Indonesia No. 30 Tahun 2004 Tentang Jabatan Notaris

2. Undang-Undang Republik Indonesia No. 2 Tahun 2014 Tentang perubahan Atas Undang-Undang No. 30 Tahun 2004 tentang Jabatan Notaris

3. Undang-Undang Nomor 31 Tahun 2014 Tentang Perubahan Atas UU No. 13 Tahun 2006 Mengenai Perlindungan Saksi dan Korban

4. Undang-Undang No 13 Tahun 2006 Mengenai Perlindungan Saksi dan Korban. Sumber bahan hukum sekunder diperoleh dari kajian pustaka, berupa jurnal hukum dan internet. Pada penelitian ini juga menggunakan bahan hukum tersier yaitu Kamus Hukum dan Kamus Besar Bahasa Indonesia, termasuk juga buku-buku dan jurnal-jurnal hukum. Metode pengumpulan data yang digunakan dalam penulisan ini adalah menggunakan metode penelitian kepustakaan (library research).

\section{Hasil dan Pembahasan}

Saksi dalam bahasa Indonesia adalah kata benda yang berarti "orang yang melihat atau mengetahui sendiri suatu peristiwa atau kejadian (Darmita, 1976). Pengertian saksi terdapat dalam Undang- undang Nomor 31 Tahun 2014 Perubahan atas Undang- undang 13 Tahun 2006 tentang Perlindungan Saksi dan Korban (selanjutnya disebut UUPSK-P) dalam Pasal 1 menyebutkan, bahwa "saksi adalah orang yang dapat memberikan keterangan guna kepentingan penyelidikan, penyidikan, penuntutan dan pemeriksaan pada siding pengadilan tentang suatu perkara pidana yang ia dengar sendiri, ia lihat sendiri, dan/atau ia alami sendiri.". Saksi akta notaris adalah para saksi 
yang ikut serta didalam pembuatan terjadinya akta (instrumen), maka dari itulah disebut saksi instrumenter (Instrumentaire Getuigen). Dalam UUJN-P tidak menjelaskan definisi saksi instrumenter. Dalam UUJN-P disebutkan bahwa salah satu kewajiban notaris adalah membacakan akta dihadapan penghadap dengan dihadiri oleh paling sedikit 2 (dua) orang saksi dan ditandatangani pada saat itu juga oleh penghadap, saksi, dan notaris. Saksi Akta Notaris merupakan para saksi yang ikut serta di dalam pembuatan terjadinya akta (instrumen), maka dari itulah disebut Saksi Instrumenter. Saksi instrumenter dalam pembuatan akta otentik yang dibuat oleh Notaris telah dilakukan sesuai dengan syarat-syarat yang berlaku dalam UUJN-P yaitu :

a. paling rendah berumur delapan belas tahun atau sebelumnya telah menikah, cakap melakukan perbuatan hukum,

b. mengerti bahasa yang digunakan dalam Akta,

c. dapat membubuhkan tanda tangan dan paraf; serta tidak mempunyai hubungan perkawinan atau hubungan darah dalam garis lurus ke atas atau ke bawah tanpa pembatasan derajat dan garis ke samping sampai dengan derajat ketiga dengan Notaris atau para pihak.

d. Saksi sebagaimana dimaksud harus dikenal oleh Notaris atau diperkenalkan kepada Notaris atau diterangkan tentang identitas dan kewenangannya kepada Notaris oleh penghadap. Pengenalan atau pernyataan tentang identitas dan kewenangan saksi dinyatakan secara tegas dalam Akta.

Ketentuan Pasal 40 UUJN-P menjelaskan bahwa tugas saksi instrumenter yang berjumlah minimal dua orang hadir dalam pembacaan akta, membubuhkan tanda tangan dan memberikan kesaksian tentang kebenaran yang disebutkan dalam akta tersebut. Sehingga keberadaan menjadi salah satu syarat formal dalam pembuatan akta autentik.

Akta autentik merupakan produk hukum yang dihasilkan oleh pejabat tertentu yang dikategorikan sebagai pejabat umum seperti Notaris (Maisyarah, 2016). Berdasarkan UUJN dan UUJNP, akta notaris dinyatakan otentik apabila :

a. Pembuatan akta notaris dilakukan di hadapan orang yang berwenang dalam hal tersebut.

b. Terdapat tanggal pasti kapan dibuatnya akta.

c. Terdapat data pasti mengenai siapa pejabat yang menandatangani akta dan terdapat tanda tangan orang yang bersangkutan dalam akta.

d. Notaris telah memberikan sarannya saat pembuatan akta belum dilangsungkan dalam hal mana yang dibolehkan oleh ketentuan undang-undang yang berlaku dan mana yang tidak.

e. Jika ada pihak yang tidak setuju dengan kebenaran isi akta, maka ia harus membuktikan kebenaran isi akta,

f. Akta Notaris bersifat rahasia.

UUJN-P menjelaskan bahwa notaris sebagai pejabat umum yang membuat akta otentik wajib merahasiakan isi akta dan segala keterangan yang diperoleh sepanjang masa jabatan. Notaris. UUJN dan UUJN-P mengatur tentang kerahasiaan isi akta dalam sumpah jabatan notaris (Pasal 4 ayat 92) UUJN dan kewajiban notaris Pasal 16 ayat (1) 
huruf $\mathrm{f}$ UUJN-P. Unsur terpenting yang harus dirahasiakan adalah isi akta dan segala sesuatu yang diperoleh dalam proses pembuatan akta. Isi akta berisi tentang kehendak dan keinginan dari pihak yang berkepentingan dalam akta, dimana badan akta memuat keterangan-keterangan yang diberikan oleh pihak-pihak yang berkepentingan dalam akta (Adjie, 2008). Sehingga hal ini perlu dirahasiakan. Pada pasal 54 UUJN-P dijelaskan bahwa notaris hanya berhak memberikan atau memberitahukan isi akta otentik kepada pihak yang berkepentingan langsung, ahli waris, atau orang lain yang memperoleh hak untuk melihat isi akta. Secara jelas dalam UUJN-P disebutkan bahwa notaris memiliki kewajiban untuk merahasiakan isi akta dan segala keterangan yang diperoleh dalam proses pembuatan akta. Sumpah jabatan notaris juga mengatur mengenai merahasiakan isi akta dan segala keterangan yang diperoleh dalam proses pembuatan akta. Berdasarkan hal tersebut maka notaris harus melaksanakan kewajiban merahasiakan hal-hal tersebut.

Sementara untuk saksi instrumenter dilihat dari kedudukan dan sifatnya sebagai saksi yang diwajibkan hadir dalam pembuatan akta notaris, yang turut mendengarkan, menyaksikan pembuatan akta dan menandatangani akta, tidak harus mengerti apa yang dibacakan dan tidak ada kewajiban untuk menyimpan isi akta dalam ingatan (Tobing, 1992). Keterlibatan saksi instrumenter dalam pembuatan akta otentik menjadikan saksi instrumenter bagian dari proses hukum. Saksi instrumenter sebagai bagian penting dalam proses pembuatan akta otentik seharusnya mempunyai kewajiban dalam merahasiakan isi akta yang ditandatanganinya, tetapi dalam UUJN-P belum diatur secara jelas mengenai kewajiban saksi instrumenter dalam merahasiakan isi akta. Tidak adanya kewajiban merahasiakan isi akta dan semua keterangan yang diperoleh dalam proses pembuatan akta oleh saksi instrumenter, menyebabkan saksi instrumenter dapat dengan mudah dimintai keterangan terkait dengan akta yang ditandatanganinya oleh pihak ke tiga atau pihak yang berwenang. Dipanggilnya saksi instrumenter oleh pihak ke tiga atau oleh pihak berwenang dapat mengakibatkan terbukanya isi akta karena tidak adanya perlindungan dan kepastian hukum bagi saksi instrumenter untuk merahasiakan isi akta. Saksi instrumenter merupakan bagian dari notaris seharusnya berkewajiban merahasiakan isi akta untuk menjaga kepentingan pihak-pihak dalam akta. Menurut teori perlindungan yang disampaikan oleh Satijipto Raharjo, bahwa mengkoordinasi berbagai kepentingan dalam masyarakat terhadap kepentingan tertentu, hanya dapat dilakukan dengan memberikan batasan kepentingan di pihak lain (Raharjo, 2000), maka untuk melindungi kepentingan para pihak yang ada di dalam akta otentik, notaris dan saksi instrumenter berkewajiban merahasiakan isi akta. Dengan memberikan penjelasan mengenai kewajiban saksi instrumenter terhadap kerahasiaan akta otentik dalam UUJN$\mathrm{P}$ akan memberikan perlindungan hukum bagi saksi instrumenter yang merupakan bagian penting dalam pembuatan akta otentik.

Kedudukan saksi instrumenter dalam fungsinya untuk memenuhi persyaratan formalitas akta Notaris ditentukan pada Pasal 38 ayat (4) huruf c UUJN Nomor 30 Tahun 2004 tentang Jabatan Notaris, Pasal 1868 KUH Perdata serta Pasal 40 ayat (1) UUJN-P. 
Berdasarkan UUJN-P secara hukum saksi instrumenter kedudukannya tidak diwajibkan secara pasti harus menjaga kerahasiaan isi akta. Saksi instrumenter yang tidak menjaga kerahasiaan dokumen Notaris perbuatannya diklasifikasikan perbuatan melawan hukum.

Undang-Undang memberikan pengaturan dan perlindungan terhadap notaris dalam menjalankan jabatannya secara khusus dalam pasal 66 ayat (1) UUJN dengan persetujuan Majelis Kehormatan Notaris yaitu dengan memberikan surat permohonan. Apabila notaris lalai atau kurang hati-hati dalam menjalankan tugas sebagai pejabat umum yang membuat akta Otentik, Notaris dapat digugat oleh para pihak atau klien nya yang merasa dirugikan sebagai akibat dari akta otentik yang dibuat oleh Notaris, dalam hal ini dapat notaris digugat secara perdata maupun pidana.

Saksi instrumenter dalam pembuatan akta memiliki peran penting dalam menjadikan akta otentik, saksi instrumenter juga dikatakan sudah masuk ke dalam lalu lintas hukum yang memiliki akibat hukum, maka saksi instrumenter seharusnya memiliki perlindungan hukum dan harus dijamin keselamatannya apabila terjadi kasus atau gugatan di pengadilan terhadap akta yang menjadikannya saksi. Saksi instrumenter memiliki hak sebagai saksi yang diatur dalam Pasal 5 ayat (1) Undang-Undang Nomor 13 Tahun 2006

Tentang Perlindungan Saksi dan Korban, yaitu:

a. Memperoleh perlindungan atas keamanan pribadi, keluarga, dan harta bendanya, serta bebas dari ancaman yang berkenan dengan kesaksian yang akan, sedang atau telah diberikannya.

b. Ikut serta dalam proses memilih dan menentukan bentuk perlindungan dan dukungan keamanan

c. Memberikan keterangan tanpa tekanan

d. Mendapat penerjemah

e. Bebas dari pertanyaan yang menjerat

f. Mendapatkan informasi mengenai perkembangan kasus

g. Mendapatkan informasi mengenai putusan pengadilan

h. Mengetahui dalam hal terpidana dibebaskan

i. Mendapat identitas baru

j. Mendapat tempat kediaman baru

k. Mendapat nasihat hukum

1. Memperoleh bantuan biaya hidup sementara sampai batas waktu perlindungan berakhir.

Saksi instrumenter dalam memberikan keterangan perihal akta yang ditandatanganinya, mendapatkan perlindungan sebagaimana Notaris jika dijadikan saksi di depan persidangan. Undang-Undang Perlindungan Saksi dan Korban menjelaskan bahwa seseorang mendapatkan perlindungan oleh Lembaga Perlindungan saksi dan Korban sejak dimulainya penyelidikan hingga berakhirnya proses hukum. Pada Pasal 5 ayat (1) huruf a Undang-Undang Perlindungan Saksi dan Korban menyatakan bahwa "Memperoleh perlindungan atas keamanan pribadi, keluarga 
dan harta bendanya, serta bebas dari ancaman yang berkenaan dengan kesaksian yang akan, sedang, atau telah diberikannya".

\section{Kesimpulan}

Berdasarkan uraian di atas dapat disimpulkan bahwa saksi instrumenter yang bertugas membubuhkan tanda tangan, memberikan kesaksian tentang kebenaran isi akta dalam proses pembuatan akta otentik menurut UUJN dan UUJN-P tidak dijelaskan kewajibannya dalam merahasiakan isi akta, tetapi saksi instrumenter yang tidak menjaga kerahasiaan dokumen notaris perbuatannya diklasifikasikan sebagai perbuatan melawan hukum. Kemudian perlindungan hukum saksi instrumenter tidak ditegaskan dalam UUJN dan UUJN-P tetapi apabila suatu hari terjadi sesuatu terhadap akta otentik yang ditandatanganinya yang menjadikan saksi instrumenter terlibat masalah hukum, maka saksi instrumenter mendapat perlindungan sebagai saksi sesuai dengan UndangUndang Perlindungan Saksi dan Korban pasal 5. 


\section{BIBLIOGRAFI}

Adjie, Habib. (2008). Hukum Notaris Indonesia: Tafsir Tematik Terhadap UU No. 30 Tahun 2004 Tentang Jabatan Notaris. Bandung: Refika Aditama. Google Scholar

Budiardjo, Miriam. (2003). Dasar-dasar ilmu politik. Jakarta: Gramedia pustaka utama. Google Scholar

Dhaniaty, M. (2019). Kedudukan Saksi Instrumentair Atas Akta Notaris yang Menimbulkan Permasalahan dalam Perkara Perdata . Jurnal Media Hukum dan Peradilan. Google Scholar

Darmita, P. (1976). Kamus Umum Bahasa Indonesia. Jakarta: Balai Pustaka. Google Scholar

Hamzani, Achmad Irwan. (2014). Menggagas Indonesia Sebagai Negara Hukum Yang Membahagiakan Rakyatnya. Yustisia Jurnal Hukum, 3(3), 137-142. Google Scholar

Hendra, Rahmad. (2012). Tanggungjawab Notaris Terhadap Akta Otentik Yang Penghadapnya Mempergunakan Identitas Palsu di Kota Pekanbaru. Jurnal Ilmu Hukum, 3(1). Google Scholar

Hutapea, H. N. (2016). Kedudukan Saksi Instrumenter Dalam Hukum Nasional. Jurnal Unimed, Universitas Medan, Jurnal Hukum Vol 8 No 2. Google Scholar

I Komang Sujanayasa, P. D. (2016). Kedudukan Saksi Instrumentair Akta Notaris dalam Kaitanya dengan Pasal 16 ayat (1) Undang-Undang No.30 Tahun 2004 Tentang Jabatan Notaris. Acta Comitas. Google Scholar

Kusuma, A. R. (2018). Perlindungan Hukum Saksi Instrumenter di dalam Akta Notaris. Tesis. Google Scholar

Maisyarah, Intan. (2016). Analisis Yuridis Tentang Kedudukansaksi Dalam Pembuatan Akta Notariil Menurut Hukum Islam Dan Undang-undang Jabatan Notaris (Uujn). Premise Law Journal, 14, 164860. Google Scholar

Raharjo, Satjipto. (2000). Ilmu Hukum. PT Citra Aditya Bakti. Google Scholar

Romadhon, A. A. (2018). Peranan Saksi Instrumenter dan Akibat Hukumnya Terhadap Kerahasiaan Dalam Pembuatan Akta Notariil. Google Scholar

Soekanto, Soerjono, \& Mamudji, Sri. (2001). Penelitian hukum normatif: Suatu tinjauan singkat. Raja Grafindo Persada. Google Scholar

Syaputri, Hijriah Maulani Nanda, Patittingi, Farida, \& Said, Nurfaidah. (2017). Aspek Hukum Kewajiban Saksi Instrumentair untuk Merahasiakan Isi Akta Notaris. Amanna Gappa, 25-37. Google Scholar

Tobing, G. L. (1992). Peraturan Jabatan Notaris. Jakarta: Erlangga. Google Scholar 


\section{Copyright holder:}

Puteri Chintami Oktavianti (2021)

First publication right:

Journal Syntax Literate

This article is licensed under:

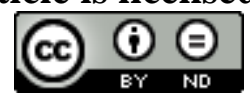

